\title{
Mysterious Gear: Modernist Mountaineering, Oxygen Rigs, and the Politics of Breath
}

\section{Abbie Garrington}

In 'Mountains', one of the 'Ariel Poems' series of pamphlets published as Christmas cards by Faber in 1954, and the third of his series of 'Bucolics', W. H. Auden takes this moment, one year on from the close of the Everest era with the Hillary/Tenzing ascent of that mountain, as an apposite point from which to view the strange tribe of the mountaineer: ${ }^{1}$

And it is curious how often in steep places

You meet someone short who frowns,

A type you catch beheading daisies with a stick;

Small crooks flourish in big towns

But perfect monsters-remember Dracula-

Are bred on crags in castles: those unsmiling parties,

Clumping off at dawn in the gear of their mystery

For points up, are a bit alarming;

They have the balance, nerve

And habit of the Spiritual, but what God

Does their Order serve? ${ }^{2}$
A. Garrington $(\bowtie)$
Department of English Studies, Durham University, Durham, UK
(C) The Author(s) 2021
D. Fuller et al. (eds.), The Life of Breath in Literature, Culture
and Medicine, Palgrave Studies in Literature, Science and Medicine, https://doi.org/10.1007/978-3-030-74443-4_19

391 
Short, monstrous, cruel to the merest daisy, the mountaineer rises with the sun (which is in fact rather late for an Alpine start, the icepack at risk of melt and shift by that point), but he greets that dawn with an absent smile and the leaden foot of his climbing boot, weighting himself and Auden's line with a '[c]lumping' step. Such boots are part of the mysterious 'gear' of the climber, akin to the 'habit' of their monkish brothers who might also be found in the heights. ' $[\mathrm{H}]$ abit' and 'Order' mix religious observance with the lumpen clumping of the ritualised yet most likely non-spiritual brotherhood of the rope. Their 'balance' and 'nerve' are necessities, but to what end, given the self-selected heroism of a dangerous climb, the purposelessness of the endeavour? Their 'gear'their kit and paraphernalia-marks them as men apart, or as cranks perhaps (we note here that Basil Bunting's 'On the Flyleaf of Pound's Cantos' of 1949 refers to 'crags cranks climb'). ' 'Gear' also, with the oxygen rigs, snow goggles, and ever-developing ice axes of that Everest era in mind, ${ }^{4}$ indicates the semi-technological body of the mountaineer, the near-automaton, whose incorporation of or bodily negotiation with mechanisms places him alongside the airman of the period, a second figure reliant upon systems of oxygen supply, technologies of the breath. In Cecil Day-Lewis's ballad 'Johnny Head-in-Air' of 1935, a voice asks of travellers burdened with a combination of kit and superstitions: 'Where are you going, you wan hikers, / And why this ganglion gear? 5 In this reading, the body's uneasy appeasement with its burdens makes of them a kind of cyst, a 'ganglion'. Meanwhile, via its Middle English origins, 'gear' indicates a mechanism, suitable for ratcheting-up or raisinghigh-as does 'crank', of course. Whatever their balance and nerve, then, Auden's mountaineers' ascension causes 'alarm'-through sombre disposition and get-up (a get-up for getting up, we might say); through 'cranked' displacement into the rare air of high altitude; and through the opaque motivations of their high-risk, seemingly low-outcome practices.

Auden's landscape in 'Mountains' is, we gather, primarily supposed to indicate Alpine rather than Himalayan realms - if there are daisies in the foothills, and if the dawn departure of mountaineers is, it is implied, observed from a town location, then these are the 'steep places' of the Alps, and not the disorientatingly vertiginous peaks of the 'roof of the world'. ${ }^{6}$ The monastic group hinted at in the extract's final lines may therefore be taken as a reference to the Carthusians, an enclosed Roman Catholic order founded by St Bruno of Cologne in 1084, in the valley of the Chartreuse of the French Alps. ${ }^{7}$ Their motto, 'stat crux volvitur 
orbis' [the cross is steady while the world turns], is one possible source of the surname of loyal and reliable Ian Shawcross (or sure cross), one of the climbing party featured in Auden and Christopher Isherwood's mountaineering verse drama The Ascent of F6: A Tragedy in Two Acts, which was first performed in $1937 .{ }^{8}$ The Carthusians' precursors, the Desert Fathers, make an appearance in Matthew Arnold's 'Stanzas from the Grande Chartreuse' of 1855, the rhythms of which turn up in the play's oft-cited and frequently misinterpreted funeral dirge known by its opening phrase, 'Stop all the clocks'. ' And if we are after all in an Alpine context, the 'gear of [the climbers'] mystery' might indicate only that they are supplied with sun goggles, hobnailed boots, hats, and veils for sun protection (the latter perhaps recalling a monkish 'habit'), with ice axes, and coils of rope. Yet, given the year of publication, with images of the Everest ascent fresh in the mind, and as a long-term observer of British attempts upon that mountain, Auden may also be overlapping his Alps and Himalayas, in a palimpsestic presentation of mountain vistas. Maurice Herzog, whose Annapurna of 1951 is often claimed to be the biggest-selling work of mountaineering literature of all time, ${ }^{10}$ exported the Alps as a means of physical and psychological measure when confronting this unclimbed $8,000 \mathrm{~m}$-plus peak (the first of such height to be summitted), continually using 'Mont Blanc' as a point of comparison interposed between climber and the Himalayan landscape with which he was actually faced ('The height, which was about the same as that of Mont Blanc, was making us tired'). ${ }^{11}$ Auden's movement is in the other direction, having Everest (and its own 'Order[s]' of Buddhism, seemingly drawn from British accounts of access to the mountain via Tibet in the 1920s $)^{12}$ hover around, or loom over, a more familiar Alpine view. The Alpine/Himalayan collapse or conflation of Auden's poem is useful to us not only in suggesting that the climbers' 'gear' indicated here might reasonably include a contraption of oxygen supply (albeit that its mask or mouthpiece must be removed for us to register the climbers' 'unsmiling' faces), but also in suggesting that the shift toward the Greater Ranges, and to the use of modifications of or supplements to the human breath necessitated by climbs at higher altitudes, might cause problems for the contraption of poetry itself. If Everest had 'fallen' to the human foot (and, as Jan Morris's renowned account of the 1953 climb Coronation Everest hinted at its close, to the Commonwealth), ${ }^{13}$ the poetic treatment of mountaineering struggled to transfer to these heights, weighed down by Romantic and Victorian conceptualisations of human struggle 
against rock, by Alpine landscapes that no longer formed the arena of greatest challenge for the contemporary mountaineer, by the remnants of mountain spirituality in an era of scientific and sporting impetus, and by the imperfect incorporation of the mysterious gear of the high-altitude mountaineer's oxygen supply. ${ }^{14}$

The only member of the climbing party to take part in all three British attempts upon Everest in the 1920s (that is, a reconnaissance in 1921, and bids to reach the summit in 1922 and 1924) was George Leigh Mallory. Now perhaps the most famous climber in Western mountain history, following his death alongside climbing partner Andrew 'Sandy' Irvine on that 1924 expedition, ${ }^{15}$ Mallory is also of interest to scholars of modernist culture as a figure peripheral to the 'secret' society of the Cambridge Apostles (including biographer Lytton Strachey and economist John Maynard Keynes), and to Virginia Woolf et al.'s Bloomsbury Group. The latter circle's Duncan Grant photographed and painted the famously alluring Mallory from the life ('Mon dieu!- George Mallory! When that's been written, what more need be said?' writes Strachey in a self-satirisingly lascivious letter to Clive and Vanessa Bell), ${ }^{16}$ leading the climber to declare that 'I am profoundly interested in the nude me'. ${ }^{17}$ Yet Mallory's interest in physical form was, as we might expect of a modern mountaineer, accompanied by interests in physiology, including the intersection of the respiratory elements of the human somatic system, and the environment of high-altitude mountaineering. In an address entitled 'Purer Air than Mortals', read before the Joint Meeting of London's Alpine Club and the Royal Geographical Society on 16 October 1922, and reflecting on that year's first effort in earnest to reach the summit of Everest, Mallory describes a shift in the conception of the effort to ascend:

When first the prospect of going to Mount Everest opened for me I used to visualize the expedition in my thoughts as a series of tremendous panting efforts up the final slopes. Later it became a symbol of adventure [...]. Now it has become a problem [...] the expedition brings to my mind's eye a view of the mountain slopes set at intervals with groups of little tents, with loads of stores and sleeping sacks, and with men. ${ }^{18}$

This move from armchair imaginings of noble struggle to a focus upon local geography, strategy, and expeditionary logistics shows the potentially self-aggrandising stuffing knocked out of the man in the course of two 
previous expeditions. Yet 'tremendous panting efforts' remain in play, not least because those loads and stores would include the oxygen rigs that were eventually to make possible the successful ascent of the mountain (albeit on Hillary and Tenzing's, not Mallory's, watch).

It is notable, however, that Mallory's first bid to explain to his audience the experience of climbing on Everest's flanks omits technological measures for the supply of supplementary oxygen, favouring instead a lung-versus-mountain model that praises his own modification of the breath, and affords him brothers-in-arms (or -in-lungs) in fellow climbers with similar respiratory abilities:

Ultimately, the power of pushing up depended on lung capacity. Lungs governed our speed, making the pace a miserable crawl. From the Alpine point of view our lungs made us pause to admire the view oftener than is correct in the best circles. But our [Mallory; Dr Howard Somervell; Edward F. Norton] lungs were remarkably alike and went well together. Personally I contrived a looseness of the muscles by making an easy, deepdrawn breath, and by exercising deep breathing I found myself able to proceed. ${ }^{19}$

The repetition of the word 'lung' here (a term carrying its own weight in expired breath akin to the bell toll, and echoing into, we presume, the Great Hall of the RGS's Lowther Lodge as Mallory spoke) centres attention upon the body and its capacities, connects men of the 'right sort' in physical terms (underscoring their status as the 'right sort' in ethnic and social terms, Sherpa support on the mountain more than matching their ease at altitude, but being sidelined here), ${ }^{20}$ and puts forward the 'deepdrawn' breath, the inspiration of the gifted mountaineer, as a means of oxygen management. This apparently retrogressive or at least rudimentary approach to retention of oxygen levels and prevention of hypoxia, or what was at this time gathered under the umbrella term 'mountain sickness', is then drawn into a curious confrontation with the scientific establishment, apparently performed to elicit 'you tell 'em's from Mallory's immediate audience:

I imagine that a number of physiologists, especially, would be inclined to reduce these odds on the mountain [winning out against man]. I was told at Oxford last year, by Sir Walter Raleigh, that the physiologists said it was physiologically impossible to climb to the top of Mount Everest 
without oxygen - the matter had been proved by experiments in a pressurereducing chamber. I told Sir Walter that the physiologists might explode themselves in their diabolical chamber, but we would do what we could to explode their damnable heresy - or words to that effect. I always, as a matter of course, take off my hat to scientists, as latter-day Olympians breathing a different if not purer air than common mortals. But the air of Mount Olympus (a base little lump after all) is not that of Mount Everest, and experiments made there with a pumped-out tank, interesting as they may be, are of no value in determining where precisely on that other hill of unrivalled altitude persevering man will be brought to a standstill. ${ }^{21}$

This statement deploys scientific terminology in such a manner as to undermine it, or at least hold it forth as a peculiarity ('the physiologists said it was physiologically impossible'; 'a pressure-reducing chamber', my emphasis), and shifts the experiments of scientists from laboratory to hellscape ('their diabolical chamber') or half-imagined Greek mountain ('Olympus') brought low (a 'base [...] lump' to set against Everest's unrivalled height and widely acknowledged beauty). Yet it is explosions that are central here, indicating not only the modified pressures of a barometric chamber, but the physical and psychological pressures of the mountain experiences they were aiming to replicate. Further, the 'heresies' of Science's claim to have the answer to access to the so-called 'Third Pole', the world's roof (or a heaven to stand against the heretics), will be exploded by mountaineer testimony. Mallory performs a model of exploratory masculinity here that places faith in the capacities of man in physical and mental terms. He also breaks the frame of that continent, reticent figure of the British explorer in recounting a kind of social explosion in front of Sir Walter (although 'or words to that effect' suggests this confrontation may have been embroidered after the fact, no corroboration being available, since Sir Walter had obligingly died five months before Mallory's address).

The climber's words are surprising on two further counts. First, his scepticism toward mechanisms of oxygen supply was considerably less extensive than he indicates here, and in fact he goes on to say that 'It will be remembered that Somervell and I when we went up for the third attempt this year intended to use oxygen'. ${ }^{22}$ In 1924 Mallory returned to such use. Second, his statement that it is lived experience on the mountain's highest reaches, the testimony of the mountain elite who have actually breathed Everest's 'purer air', that takes precedence 
over laboratory experiments, anticipates the trajectory of respiratory physiology across the twentieth and twenty-first centuries. Mallory states that 'the idea of the man who has tried as to how much higher he might go should be of incomparably more value than any conclusion proceeding merely from a laboratory'. ${ }^{23}$ The contemporary historian of science Vanessa Heggie states that respiration at altitude is 'an area of research where the use of laboratory-generated standard models produced deeply misleading conclusions about the embodied human experience of the natural world'. ${ }^{24}$ As a result, Everest in the first half of the twentieth century becomes both field site and a kind of "natural laboratory $^{25}$ - one which provided, via experience and sacrifice, the only answers to the maintenance of human breath at altitude, just as Mallory had, rather theatrically, claimed in 1922. Thus an acute anticipatory observation about the location of scientific progress-'on the hill', as climbing parlance has it-is disguised in a pose of apparent scepticism toward sciences of the breath more generally.

Mallory had numerous speaking engagements upon his return to the UK following the 1922 expedition, of which the speech considered above (later published in the Alpine Journal under the more sober title of 'The Second Mount Everest Expedition') was perhaps the most important with a view to logistical planning for later attempts. He also undertook a lecture tour, sometimes speaking in partial repayment of sponsorship for the notoriously expensive 1922 trip, and sometimes to gather muchneeded funds for the next. Yet he also troubled himself to make school visits to deliver inspiring and improving talks to young scholars, usually boys, during which he both recounted the adventures of his two Everest journeys, and gave some sense of the type of character (more properly, the type of masculinity) necessary for success in ambitious expeditions, or in the wider life for which they might be seen to provide an exemplar. One such visit was paid to Gresham's School, where Mallory gave an assembly address before an audience of boys we can reasonably presume to have included the young Wystan Auden. No records are held by the school regarding who was in attendance for the mountaineer's presentation that day, but the appearance of the poem 'Everest', written in late 1922 , among the poet's juvenilia must surely confirm that Mallory had come into his ken:

Far up into the amethystine vapours Towers the ridge in white immensity 
Gazing at the stars that burn like tapers

Deep in the sky that is Eternity

$[\ldots]$

You see the fall of the Gods of yesterday And the fall of the Gods of the morrow

Yet never a sigh or regret you say

For the infinite ocean of sorrow $[\ldots]^{26}$

The poem somewhat embarrasses the tentative Auden in cleaving too visibly to Romantic influences, and this is conspicuously verse written before the young poet finds his own voice (Auden scholars generally pinning that maturation to 'The crux left of the watershed', and therefore to the scarred landscapes of post-industrial Britain rather than to Himalayan 'immensit[ies]'). ${ }^{27}$ 'Everest' is a poem written in 1922, a high watermark year of 'high' or experimental modernism from which it is distant, but also the year marking the true opening of the Everest era with the first concerted attempt to ascend. It forms a useful point of contrast, therefore, with 1954's 'Mountains', written when Everest has recently been climbed, photographs taken and splashed across newspapers, and the heights are no longer a mystery, having been surveyed not only by distant instruments but, at last, by human eyes. At first, the earlier poem seems a more landscape-focussed work, with human struggle and point of view removed, although the 'towering ridge' does suggest the close-up view of the climber (or how else are we to see past the 'vapours'?), and 'sigh[s]' and 'sorrows' are on the page, if not attributed to a climbing figure: all assisting in the registration of effort involved in what is elsewhere in the poem referred to as the 'vain' effort to reach the 'head' of the mountain. Despite these hints of the laboured breath, the work is retrospective in its poetic model, for all that Mallory, the very model of the modern mountaineer, was its likely catalyst. In fact, it might be Mallory himself who permits Auden's at this stage customary turn toward Romantic formulations, since the climber is himself enamoured of the work of Shelley, writing to Eleanor 'Marjorie' Holmes in 1924: 'Do you know Shelley? One of the greatest spirits that have appeared on earth \& a man of such moral beauty that I feel dazzled in his presence-I can't tell you how profound a feeling I have for Shelley; he has influenced my life more than any one'. ${ }^{28}$ One possible conduit of this influence is Robert Bridges, Poet 
Laureate 1913-1930, whose anthology The Spirit of Man was taken on the British Everest expeditions, and contains forty-three works or extracts by the poet. ${ }^{29}$ Katherine Bucknell, annotating 'Everest' in Auden's Juvenilia, suggests that the poem 'apparently borrows its heightened tone and its grandiose imagery of absolutes from Shelley's "Mont Blanc", although she does not give Mallory, or Bridges, as Auden's excuse for so conspicuous an influence. ${ }^{30}$ By 1954, Auden is able, as an older man, and a mature poetic voice, to identify the 'crank' aspect in the breed of climbers, and to establish an ironic distance from this noble quest to the heights, a distance that seems to interpose leaden poetic feet in order to register the sensory and somatic distancing of the climber isolated behind the gear of his oxygen rig.

In the shift from 1922 to 1954 , Auden in fact allows us to track the movement of mystery from the mountain itself, to the tightly knit band of the mountaineers' rope line or climbing party. One reason for this shift is that the mountain, now 'conquered' (as the newspapers of 1953 had it), had apparently relinquished its mystery. Yet we could also argue that the mountaineer had become more mysterious, less recognisable, in literal and metaphorical terms (that is, both facially obscured and less familiar), by the application of an oxygen rig and breathing mask. In the mountaineering literature, it is the obscuration of the face that proves a flashpoint for debates about the necessity or even seemliness of using additional oxygen. Everest mountaineer and author Graham Hoyland, writing in 2013, states that a 'flinching away from the use of supplementary oxygen' is discernible among climbers of Mallory's era, a refusal that he attributes to experience in the Great War: 'Poison gas during the [W] ar had been regarded with particular abhorrence as a cowardly form of warfare. Gas masks were dehumanising in appearance and were a horrific reminder to this group of men who had been so scarred by the [W]ar'. ${ }^{31}$ This explanation complicates the more familiar reading to which Mallory's confrontation with Sir Walter seems to contribute, in which the 'natural' capacities of the male body allow for a more sportsmanlike attempt upon a peak, while also valorising embodied knowledge. In fact, it is in the matter of the experienced body, the notion of corporeal witnessing, that mountaineer testimony in Heggie's 'natural laboratory' of Everest and the matter of war service might be seen to overlap. While the Alpine Club and RGS's 'old guard', in charge of the plans and the purse strings, were for the most part the wrong generation to have seen active service in the Great War, those around Mallory's age and younger had known that 
conflict. While Hoyland is right to read the supply of oxygen as visually corresponding to the prevention of access of noxious gases, the young guns in the Everest climbing party might in fact have been more tempted to use all means necessary to assist physical survival, lest they recreate on the slopes of the mountain General Haig's slow adaptation to the machine gun on the Western Front, with ghastly results.

Wade Davis, the historian who has done most to link Great War experience and the exploits of the Everest era, concurs with aspects of Hoyland's claims, stating that to use supplementary oxygen at altitude was not so much a technical challenge as an 'ethical and aesthetic' one. ${ }^{32}$ 'The very notion of using a gas mask was haunting', he writes. 'To climb the mountain with one's face covered in anonymity by an apparatus so powerfully evocative of the trenches seems less than heroic'. ${ }^{3}$ The model of the 'hero' is unstable here, with the oxygen/gas mask anonymising the individual, and therefore placing him among a mass; a loss of distinctive identity that damages heroic status, even as it puts the mountaineer in the company of those whose lives were bravely sacrificed as 'cannon fodder'. Davis's focus on the notion of heroism and mountaineering's relationship with Great War service skews his reading somewhat, since broader questions from the 1920s onwards regarding the frightening physical incorporation of the machinic in cyborg figures - questions brought about by newly technologised working practices - must also be in play. ${ }^{34}$ Yet the notion of 'facing' the mountain, making an individual, individuated, attempt to ascend, without the interposition of an apparatus between the face of human and of rock (or ice, or snow), remains strong in these years. To fail to 'face up' to the challenge, to use a get-up for getting up, could rig you up for laughter. Arthur Hinks, astronomer, academic cartographer, and joint honorary secretary to the Mount Everest Committee in the 1920s, writes in a letter to General Charles Bruce, leader of the 1922 and 1924 expeditions:

This afternoon we go to see a gas drill. They have contrived a most wonderful apparatus, which will make you die laughing. Pray see that a picture of [George Ingle] Finch in his patent climbing outfit with the gas apparatus is taken by the official photographer. I would gladly put a little money on Mallory to go to $25,000 \mathrm{ft}$ without assistance of four cylinders and a mask. ${ }^{35}$ 
Gifted chemist Finch's contribution to the development of the 'wonderful apparatus', and to high-altitude respiratory physiology more broadly, is highly significant, and what seems here to be an attempt to depict him as a 'crank' or pottering inventor might well be prejudice on grounds of nation and class, since Hinks was to go on to refuse Finch participation in the 1924 expedition, ostensibly as a punishment for his making personal gains from lecturing, but more probably to prevent an Australian being part of the otherwise British climbing party. ${ }^{36}$ Hinks, more than others, deploys the use of supplements to the breath, or rather their rejection, to indicate the 'right sort' of man for the job, far beyond the question of lung capacity. Mallory's humorously outraged lecture performance at the RGS should be read in this light.

Even Finch's fellow expedition participants in 1922, men themselves bound as a strange 'Order' in Auden's terms, found the scientist a curiosity in his interests, for all that those interests aimed only to shore up a successful ascent. Surgeon-mountaineer Somervell was the author of a ditty, 'When George Finch Starts to Gas', whose relentless anapestic tetrameter, $\mathrm{AABB}$ rhyme scheme, and repetition of 'oxygen drill' both echo the disappointingly repetitive nature of the drill itself, and suggest that it might have been sung at the beleaguered Finch as a kind of ungainly ballad. '[T] gas' here serves double duty, referring to the taking of oxygen, and to 'gassing', or relentless chatter-Finch's enthusiastic attempts to explain his methods have obviously been received as a barrage of ill-understood jargon:

$[\ldots]$

Have you theories precise on the subject of gas?

Respiration, and so on, and action in mass?

The exactest of thought will appear rude and boorish

Compared to the latest in science from Zurich.

Do you think that you know about altitudes high

And what kind of glass keeps the sun from your eye?

On such questions your ignorance really is crass

But you'll soon be made wise when George Finch starts to gas.

So put down your books, come along learn the knack

Of hoisting the cylinders on to your back.

For if you'd be the victor of Everest's hill

You must finish each morning with Oxygen Drill. ${ }^{37}$

The phrase 'Do you think that you know...' reiterates the attitudes discussed in this essay, where field experience is apparently superseded 
by 'the latest in science', i.e., laboratory findings; a second-placing of embodied experience resisted by many an early twentieth-century mountaineer. Somervell, whose composition is signed 'a mon ami [to my friend] G.F.', deploys a hint of the 'crank' persona to convey Finch's cherished scientific interests and his cleaving to 'drill', but the latter man was in fact more circumspect about what could or could not be achieved by developments in the delivery of supplemental oxygen at altitude, writing: 'Oxygen renders available [to the climber] more of his store of energy and hastens his steps, but it does not, alas! fit the wings of Mercury on his feet'. ${ }^{38}$ Reattributing climbing capacity to the climber himself ('his store of energy'), Finch figures the oxygen rig as a means of access- to one's reserves of power, and therefore to the summit-in a way that in fact recalls Mallory's 1922 imaginings regarding the optimal placement of kit stores and camps. In both of these accounts of the oxygen apparatus, it is curious to note the presence of other substances beyond oxygen itself, with laughing gas implied by Hinks's somewhat cruel caricature (and we might note that gas's nitrous oxide is an oxidiser, therefore similar in function to molecular oxygen, and sharing a metallic taste with altitude-what mountain writer Nan Shepherd in 1945 called 'the tang of height'), 39 while Mercury, primarily indicating a Roman god and thence the fleet of foot, also names a poison. Both Bruce and Finch's statements suggest that, start breathing things in-break the continence of the manly body under the duress of ascension-and anything might happen.

There is no doubt that mountaineering at the Third Pole brought breath centre-stage, albeit that the history of supplementary oxygen was dogged not only by the imperfect nature of laboratory testing and the limited availability of the somatic testimony of high-altitude mountaineers, but also by attitudinal worries about sportsmanship and fair dealing, anonymity, and the Great War's trenches dragged to the heights. More contemporary studies have confirmed that oxygen levels in the blood registered in living humans in Everest's 'death zone' can be lower than those found in corpses. ${ }^{40}$ Often set at 5-6,000m-plus, but actually indicating any height above which human habitation cannot be sustained, this significant zone is hinted at in Virginia Woolf's final short story 'The Symbol', where Alpine climbers venture 'too high for breathing flesh or fur-covered life'. ${ }^{41}$ In this way, Everest mountaineers, always haunted by the 'saints' and 'angels' of past climbers (in the parlance), might also be considered, in terms of the breath, the walking (or climbing) dead. 
On the Everest expeditions, whether in the 1920s or the 1950s, negotiations with the breath were necessary, maintaining the impression of 'going well' being crucial to selection as a member of the climbing team for the final push to the summit (both Mallory and Hillary recall such jockeying for position, while Auden's steady Ian Shawcross sulks about his chances). ${ }^{42}$ Tangling with the necessity of supplemental oxygen was also important, both in terms of available strength when climbing (Hillary's oxygen rig weighed 32 pounds or around 14.5 kilograms when fitted with all four canisters), ${ }^{43}$ and with regard to your post-climb and posthumous renown. Reputational matters shift, of course, with subsequent generations of climbers, while training regimens, kit, and logistics are ever more refined, and in 1978 it was shown, at long last, that Everest could be climbed without oxygen. In his account of the trip, successful summiteer Reinhold Messner, in a line that ties together mountaineering, poetry, and breath with beauty and brevity, states: 'In my state of spiritual abstraction, I no longer belong to myself and to my eyesight. I am nothing more than a single narrow gasping lung, floating over the mists and the summits'. ${ }^{44}$ Yet as Auden's 'Mountains' might be read to show, the presence of an oxygen rig did not preclude such abstraction. What if (with Mallory's imagined supply lines in place) there was a breath that could never run out, and therefore your mortality in the 'death zone' could be baffled? The status of supernatural, or rather supranatural, being, in an already haunted landscape of the dead, the saints and angels, falls within your grasp, or gasp. In this way, while in the early twentieth century the oxygen rig is a symbol of human ingenuity and the cutting edge of scientific development in the mountain-laboratory, it might at the same time be seen not to escape, but rather to extend, a sense of the spiritual and the otherworldly. To breathe 'up there' is to face the mountain, albeit with an apparatus interposed between your face and that of rock and ice, but it is also perhaps to become more-than-man, in a way that ties you, via your mysterious gear, to the brotherhood, or strange 'Order', of the rope.

\section{Notes}

1. For an account of the 'Everest era' and its place within longer mountain histories, see Peter H. Hansen, The Summits of Modern Man: Mountaineering After the Enlightenment (Cambridge, MA: Harvard University Press, 2013). 
2. W. H. Auden, Bucolics III: Mountains, illus. by Edward Bawden (London: Faber, 1954), u.p.

3. Basil Bunting, 'On the Flyleaf of Pound's Cantos', in The Poems of Basil Bunting, ed. by Don Share (London: Faber, 2016), 37.

4. For a complaint regarding the limited function of the newly shortshafted ice axe of the early twentieth century, see Harold Raeburn, Mountaineering Art (New York: Frederick A. Stokes Company, 1920), 22.

5. Cecil Day-Lewis, 'Johnny Head-in-Air', in A Time to Dance and Other Poems (London: Hogarth Press, 1935), 19-24. Vanessa Heggie cautions that 'there is a strong disanalogy between the pilot and the mountaineer', given the role of exhaustion and the ascent profile in the latter case. See Heggie, 'Experimental Physiology, Everest and Oxygen: From the Ghastly Kitchens to the Gasping Lung', The British Journal for the History of Science 46/1 (2013), 138.

6. For uses of this phrase in the contemporary Press, see Collection of Newspaper Cuttings Relating to the First Everest Expedition (Edinburgh: Mountaineering and Polar Archives, National Library of Scotland), GB/A.3845.

7. On this Order see Robin Bruce Lockhart, Halfway to Heaven: The Hidden Life of the Carthusians (Kalamazoo: Cistercian Publications, 1999). The title refers to the common notion of the Alps' height as offering relative proximity to God.

8. W. H. Auden and Christopher Isherwood, The Ascent of F6: A Tragedy in Two Acts (London: Faber, 1936). For further discussion of the significance of Ian Shawcross, see Abbie Garrington, 'What Does a Modernist Mountain Mean? Auden and Isherwood's The Ascent of F6', Critical Quarterly $55 / 2$ (2013), n. 23, 43 .

9. Matthew Arnold, 'Stanzas from the Grande Chartreuse', in The Poetry of Matthew Arnold, ed. by Kenneth Allott and Miriam Farris Allott (London: Longman, 1979), 301-05.

10. See, for example, Maurice Isserman and Stewart Weaver, Fallen Giants: A History of Himalayan Mountaineering from the Age of Empire to the Age of Extremes (New Haven: Yale University Press, 2008), 252-53.

11. Maurice Herzog, Annapurna: The First Conquest of an 8,000-Metre Peak, trans. by Nea Morin and Janet Adam Smith (London: Vintage [1952], $2011), 29$.

12. For a wide selection of the newspaper reports that would have been available to Auden, see Collection of Newspaper Cuttings Relating to the First Everest Expedition (Edinburgh: Mountaineering and Polar Archives, National Library of Scotland), GB/A.3845.

13. Jan Morris, Coronation Everest (London: Faber [1958], 2003 ), 159. 
14. The Alps are regularly associated with lung health, of course, due to the prevalence of sanatoria there. It is Thomas Mann's The Magic Mountain, published in German in 1924, and first available in English in 1927, that gives the most extended literary account of such a treatment centre. Mann's wife's unspecified 'lung complaint' saw her live at Dr Friedrich Jessen's Waldsanatorium in Davos, Switzerland, and the 'Arrival' chapter of Mann's book is generally taken to be based on this experience. If the Alps are a space of lung management and treatment, the Himalayas are their space of greatest duress, with the possible exception of high-altitude flying. See Thomas Mann, The Magic Mountain, trans. by H. T. LowePorter (London: Vintage, [1927] 1999). For a recent account of the history of mountain sanatoria in this period, see Mariano Martini, et al., 'The History of Tuberculosis: The Social Role of Sanatoria for the Treatment of Tuberculosis in Italy Between the End of the $19^{\text {th }}$ Century and the Middle of the $20^{\text {th }}$, Journal of Preventive Medicine and Hygiene 59/4 (2018), 323-27.

15. For a sparsely written but moving eyewitness account of the disappearance of Mallory and Irvine, 'enveloped in cloud once more', see Noel Odell, 'Mr. Odell's Story', in 'The Mount Everest Dispatches', The Geographical Journal 64/2 (1924), 163-65. See also Noel Odell, 'The Last Climb of Mallory and Irvine', The Geographical Journal 64/6 (1924), 455-61.

16. Lytton Strachey, 'Letter to Clive and Vanessa Bell, 21 May 1909', in The Letters of Lytton Strachey, ed. by Paul Levy (London: Viking, 2006), 178-79.

17. Peter Gillman and Leni Gillman, The Wildest Dream: The Biography of George Mallory (Seattle: Mountaineers Books, 2001), 98.

18. George Mallory, 'Purer Air than Mortals: Mount Everest, 1922', in Climbing Everest: The Complete Writings of George Mallory, ed. by Peter Gillman (London: Gibson Square, 2010), 205.

19. Mallory, 'Purer Air than Morals', 213.

20. For a summary of the claims of Everest mountaineers regarding the physical adaptation of Sherpas to high altitude environments, see Sherry B. Ortner, Life and Death on Mount Everest: Sherpas and Himalayan Mountaineering (Princeton: Princeton University Press, 1999), 63-67.

21. Mallory, 'Purer Air than Mortals', 217-18.

22. Mallory, 'Purer Air than Mortals', 218.

23. Mallory, 'Purer Air than Mortals', 218.

24. Heggie, 'Experimental physiology', 126.

25. Heggie, 'Experimental physiology', 123.

26. W. H. Auden, 'Everest', in Juvenilia: Poems 1922-1928, ed. by Katherine Bucknell (Princeton: Princeton University Press, 2003), 9-10.

27. See, for example, Edward Mendelson, Early Auden (London: Faber, 1981), 27. 
28. George Mallory, 'Letter to Marjorie Holmes, 8 March 1924', Royal Geographical Society (with IBG), LMS/M48.

29. For more on Shelley's inclusion in The Spirit of Man, see Abbie Garrington, 'What does a Modernist Mountain Mean?', 39.

30. Katherine Bucknell, note to W. H. Auden, 'Everest', in Juvenilia: Poems 1922-1928, 10.

31. Graham Hoyland, Last Hours on Everest: The Gripping Story of Mallory and Irvine's Fatal Ascent (London: Collins, 2013), 61. It was Hoyland who discovered the frozen body of George Mallory, high on Everest's slopes, in 1999.

32. Wade Davis, Into the Silence: The Great War, Mallory, and the Conquest of Everest (London: The Bodley Head, 2011), 385.

33. Davis, Into the Silence, 385.

34. The best broad rehearsal of these debates is to be found in Tim Armstrong, Modernism, Technology and the Body: A Cultural Study (Cambridge: Cambridge University Press, 2008).

35. Cited by Davis, Into the Silence, 387.

36. For a summary of this clash between Finch and Hinks, see Robert Wainwright, The Remarkable Life of George Ingle Finch: Climber, Scientist, Inventor (London: Allen \& Unwin, 2016). The oxygen rigs of the 1924 expedition were left in the care of 21-year-old Sandy Irvine, a fellow chemist but, given his youth, of necessarily limited experience. Sir Edmund Hillary discusses his own use of an updated version of Finch's oxygen rig on the successful 1953 Everest expedition. See Edmund Hillary, View from the Summit (London: Corgi, 2000), 61-62.

37. Cited by Wainwright, The Remarkable Life, 206-07.

38. Davis, Into the Silence, 457.

39. Nan Shepherd, The Living Mountain: A Celebration of the Cairngorm Mountains of Scotland (Edinburgh: Canongate, [1945] 2011), 9.

40. See 'Altitude Deterioration', in High Altitude Medicine and Physiology, ed. James S. Milledge, John B. West, and Robert B. Schoene (Boca Raton: CRC Press, 2007), 47.

41. Virginia Woolf, 'The Symbol' (1941?), in A Haunted House: The Complete Shorter Fiction, ed. by Susan Dick (London: Vintage 2003), 282-84.

42. Act II Sc. I, Auden and Isherwood, The Ascent of F6, 49-50.

43. Hillary, View from the Summit, 62. For a detailed account of 'OpenCircuit' and 'Closed-Circuit' oxygen rigs, and the management of oxygen in the 1953 expedition, see John Hunt, The Ascent of Everest (London: Hodder and Stoughton, 1953), 257-59.

44. Reinhold Messner, Everest: Expedition to the Ultimate, trans. by Audrey Salkeld (London: Kaye and Ward, 1979), 180. 


\section{Selected Bibliography}

Collection of Newspaper Cuttings Relating to the First Everest Expedition. Edinburgh: Mountaineering and Polar Archives, National Library of Scotland. GB/A.3845.

Davis, Wade. 2011. Into the Silence: The Great War, Mallory, and the Conquest of Everest. London: The Bodley Head.

Gillman, Peter and Leni Gillman. 2001. The Wildest Dream: The Biography of George Mallory. Seattle: Mountaineers Books.

Hansen, Peter H. 2013. The Summits of Modern Man: Mountaineering After the Enlightenment. Cambridge, MA: Harvard University Press.

Heggie, Vanessa. 2013. Experimental Physiology, Everest and Oxygen: From the Ghastly Kitchens to the Gasping Lung. The British Journal for the History of Science, 46/1: 123-47.

Isserman, Maurice and Stewart Weaver. 2008. Fallen Giants: A History of Himalayan Mountaineering from the Age of Empire to the Age of Extremes. New Haven: Yale University Press.

Mallory, George. 2010. Purer Air than Mortals: Mount Everest, 1922. In Climbing Everest: The Complete Writings of George Mallory, ed. Peter Gillman, 205-21. London: Gibson Square.

Odell, Noel. 1924. The Last Climb of Mallory and Irvine. The Geographical Journal 64/6: 455-61.

Ortner, Sherry B. 1999. Life and Death on Mount Everest: Sherpas and Himalayan Mountaineering. Princeton: Princeton University Press.

Wainwright, Robert. 2016. The Maverick Mountaineer: The Remarkable Life of George Ingle Finch: Climber, Scientist, Inventor. London: Allen \& Unwin. 
Open Access This chapter is licensed under the terms of the Creative Commons Attribution 4.0 International License (http://creativecommons.org/licenses/ by $/ 4.0 /$ ), which permits use, sharing, adaptation, distribution and reproduction in any medium or format, as long as you give appropriate credit to the original author(s) and the source, provide a link to the Creative Commons license and indicate if changes were made.

The images or other third party material in this chapter are included in the chapter's Creative Commons license, unless indicated otherwise in a credit line to the material. If material is not included in the chapter's Creative Commons license and your intended use is not permitted by statutory regulation or exceeds the permitted use, you will need to obtain permission directly from the copyright holder.

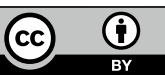

